\title{
Pragmatic Thinking in the Book of Dalail Al-I'jaz Abdul Qahir Al-Jurjani
}

\author{
Mamluatul Hasanah $^{1 *}$, Alfiatus Syarofah ${ }^{2,}$ Risna Rianti Sari ${ }^{3}$ \\ ${ }^{1}$ Maulana Malik Ibrahim State Islamic University Malang, Indonesia \\ ${ }^{2}$ Maulana Malik Ibrahim State Islamic University Malang, Indonesia \\ ${ }^{3}$ Maulana Malik Ibrahim State Islamic University Malang, Indonesia \\ *Corresponding author. Email: hasanah@pba.uin-malang.ac.id
}

\begin{abstract}
The solution to the pragmatic transfer experienced by Arabic learners can be found by re-reading Arabic turas using a pragmatic perspective born of modern linguistics. Abdul Qahir al-Jurjani's monumental work, one of the legacies of the Araby Dalail al-I'jaz turas, is studied critically with a naturalistic interpretive paradigm. It is analyzed with an intertextuality model to find its pragmatic thinking. Researchers used qualitative approach and the design was a historical text study. The results showed that Jurjani offers four pragmatic thoughts; first, producing discourse as ordered in al-nadzm theory, namely al-tandzim, al-bina', al-tartib and al-ta'liq. Second, the context offered by Jurjani uses the al-ta'dhiry al-tathbiqy approach, a blend of linguistics and ideology. The third is goal setting, and the fourth is discourse strategy. Jurjani combines linguistic and non-linguistic input in these last two cases and uses an argumentative persuasive strategy. Jurjani's offer when contextualized in solving pragmatic transfer problems is manifested in how to set learning objectives, design learning materials and learning strategies. The goal set must lead to achieving pragmatic competence. The selected material is in the form of functional texts. The chosen learning objective chooses language using a functional mindset to argumentative persuasion.
\end{abstract}

Keywords: Pragmatic thinking, Dalail al-I'jaz, Abdul Qahir al-Jurjani, Arabic Learning

\section{INTRODUCTION}

The pragmatic transfer experienced by Arabic language learners in Indonesia is caused by three things, namely the lack of metapragmatic input in the Arabic learning process, the absence of authentic discourse-based class and the lack of attention from lecturer on the realization of pragmatic competence [1]. This study seeks to find a solution to pragmatic transfer by eliminating the first cause, namely the lack of metapragmatic input in Arabic learning. It is done by conducting a dialogue between Arabic turas, the primary source of Arabic language studies, and modern linguistics initiating pragmatic problems. Among the figures who have the roots of thinking about pragmatics in linguistic turas Arabic is Abdul Qahir al-Jurjani with his linguistic theory al-nadzm. The result of this dialogue between Jurjani's thinking and modern linguistics will be the basis for providing pragmatic input.

The urgency of pragmatic input in learning Arabic, especially in the Indonesian context, is seen in achieving communicative competence as a learning goal (KMA 165 2014, KMA 185 2019). The communicative approach, in which there is pragmatic competence, is inspired by Hymes's functional linguistics, followed by Wilkins and Widdowson, who contextualized it in language learning. Then communicative competence began to be formulated by Canale \& Swain, Canal, Savignon, and Brown [2]. Attention to pragmatic competence, one of the dimensions of communicative competence, also occurs among researchers in language learning [3] [4]. Several studies have also arrived at indicator dimensions [5], which stipulates five indicators of pragmatic competence. They are the delivery of appropriate speech acts, interpretation of meaning 
according to context, delivery of appropriate role functions, delivery of appropriate pragmatic functions, and use of culture under language being studied.

Pragmatics as a science originates from several other sciences that also study language, and the factors related to the use of language, namely the philosophy of language, sociolinguistic anthropology, and linguistics - especially discourse analysis and deixis theory [6]. From the philosophy of language, pragmatics studies speech acts and conversational implicature. From sociolinguistics, pragmatics discusses language variations, communicative abilities, and language functions. Finally, from anthropology, pragmatics studies language ethics, language context, and non-verbal factors.

Pragmatics transfer in Arabic learning is still being experienced today. Many ideas and works are stored in the study of Arabic turas to be re-read as a solution to the problems in the current era. One of them is the work of Abdul Qahir al-Jurjani, namely Dalail al-I'jaz $(471 \mathrm{H}, 2016)$. There is a theory known as al-Nadhm or referred to by Jurjani as Nudhm alQur'an in this book. Jurjani uses this term to express the beauty and perfection of the Quranic language style. He is not the first person to use the term nadhm, several other figures have used this term before, both from theologians [7] and literary critics (Al Jahidh). Abdul Qohir's position from the previous figures is to reconstruct the existing concept. For his dedication, he is regarded as the developer and refiner of the concept of al-nudhm. In the realm of theology, Jurjani has reconstructed the idea of the miracles of the Qur'an, in which the mu'tazilites think that the Qur'an is a creature. Even some mu'tazilite figures deny the miracles of the Qur'an (call it for example al-Ja'd bin Dirham). Another figure named Abu Ishaq Ibrahim alNadzm considers the i'jaz al-Qur'an not to lie in the al-Qur'an itself but lies in external factors of alQur'an. The Qur'an, which is the will of Allah, made the Arabs weak and powerless to make something like it, even though they were able to make it.

Jurjani later opposed this kind of mu'tazilite thought. He said that "producing the utterance begins with compiling the grammatical meaning in the brain in a form resembling the description of the $i^{\prime} r a b$ relationship when we want to understand the utterance. In his view, four stages must be passed when someone produces speech, namely al-nadzm, albina', al-tartib and al-ta'liq. Al-nadzm is the stage where a person chooses the appropriateness of lafadz with the correct meaning. After the selection of lafadz is complete, the next stage is "al-bina" where we assemble the lafadz into sentences (jumlah). The next stage is al-tartib where someone will align the arrangement with the desired meaning and then do "alta'liq" decide and make the final choice of the speech to be expressed.

The problem raised in this research is pragmatic input in Arabic language learning. That is why maharah al-Qiraah (reading skill) is chosen as an example whose teaching materials will be reconstructed to solve the problem of pragmatic transfer. Based on this background, the research focus is formulated on two things; first, what are the pragmatic aspects of the theory of al-nadzm Abdul Qahir al-Jurjani and see it from modern linguistics. Second, how to design teaching materials based on language in use from the perspective of dialogue, alnadhm theory and pragmatics.

\section{METHOD}

This research is a historical text study. The object of this research is Arabic texts that Abdul Qahir alJurjani contained in about fifty of his writings, but only fourteen of his works can be reached by researchers. Of these fourteen works of his that discuss the theory of al-Nudhm is Dalail al-I'jaz. In this case, the researchers interpret Jurjani's thoughts in linguistics with a pragmatic perspective. Therefore, the approach used in collecting and interpreting data is a qualitative approach that is naturalistic and interpretive.

This research is qualitative because of some characteristics including; 1) data in the form of text documents containing Jurjani's thoughts are natural (natural setting), because the researchers did not treat the texts. 2) Researchers as a key instrument in collecting and interpreting data. 3) Inductive data analysis and 4) meaning is essential [8].

The paradigms in this research are interpretivism and naturalism. The reality of the text is understood as a construction of thought that requires meaning, interpretation and interpretation [8] [9]. The texts written by Jurjani are treated as a reality of thought which is mutually exclusive. The position of the researchers is as an instrument that interacts directly with the text and tries to give meaning. The key instrument of this research is the human instrument. The researchers collect the data, present the data, reduce the data, organize the data, interpret the data and conclude the research results.

When the text is understood as a reality of thought, this research is in textual linguistics which carries out two main functions [10]. First, textual description (al-wash al-nashhi) describes and narrates the phenomena displayed by the text, observes and 
maps thoughts, both implied and expressed in the text. Second, textual analysis (tahlil al-nushus), analyzing and explaining the reality of the text, interpreting the content and substance through cross-text reading. Thus, this research is based on a textual approach supported by understanding the Arabic language and the socio-cultural context, the time and place where Jurjani's works appear.

This research is categorized as historical research because of the position of the researchers with Abdul Qahir al-Jurjani and his work that spans centuries. Therefore, this kind of study is known as historical research. It will later be used as one of the stages of development research that will give birth to teaching materials based on Abdul Qahir al-Jurjani's pragmatic perspective. It is expected to solve the pragmatic transfer experienced by students learning Arabic in Indonesia.

\section{RESULT}

The majority of linguistic studies pay more attention to the analysis of language understanding or the receptive aspects of language than to its productive. If language is a communication process, the attention to understanding speech is more dominant than producing an utterance. In simple language, attention to sami' (listener) is greater than to mutakallim (speaker), even though the communication process should involve both in a balanced way. In the communication process, the two most important ends of communication are the speaker and the recipient of the speech, between them is a mission to be conveyed (the content of the speech). The task of a speaker is to produce speech and the task of the recipient of the speech is to interpret the speech received. It is as summarized by Jurjani in figure 1 .

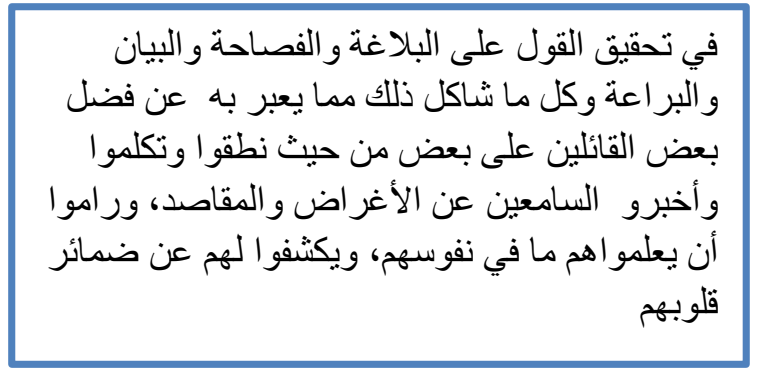

Figure 1 Al-Jurjani, Dalail al- I'jaz, 2016 • p.38

There are four aspects of pragmatics in Abdil Qahir al-Jurjani's thought found in this study. These four things will be described and viewed from the point of view of modern linguistics.

\subsection{Producing Discourse: Jurjani (al-Nudhm) vs. Chomsky (Universal Grammar)}

Jurjani, in his book Dalail al-I'jaz said that producing discourse that has fashahah, bayan, bara'ah criteria begins with compiling grammatical meanings in mind in the form of a description of the i'rab relationship when you want to convey the meaning. It covers four stages when people produce a discourse: al-tandzim, al-bina', al-tartib, and alta'liq.

Al-tandhim and Al-bina' are the stages to pass in constructing an utterance. The first thing to consider so that speech production meets the criteria is the selection of meaning and the right lafadz to represent the intended meaning. The diction chosen must be the best, the most beautiful and the most special. The selection of the right meaning and lexicon in the mind is what is called the "alTandhim" stage. The next stage that must be carried out by someone who makes speech is assembling the lexicon and meaning in an appropriate grammatical structure, whether it is in the form of news sentences, orders, prohibitions, seeking information, praising, criticizing, or others. This stage is called "al-bina" based on Jurjani's statement in figure 2 .

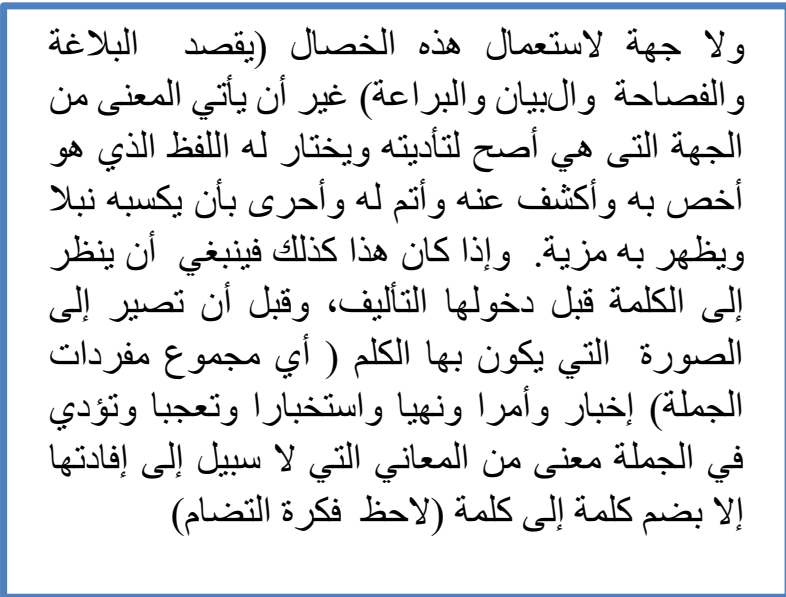

Figure 2 Al-Jurjani, Dalail al- I'jaz, 2016 • p.38

Al-Tartib and al-Ta'liq are the following process after the two stages are carried out. After the selection of diction is done correctly, and arranged in a proper grammatical manner, the next step is to sort the lexicon and meaning that we have chosen according to the grammar that we have set. It is what Jurjani called alTartib. Meanwhile, al-Ta'liq is the last stage so that an utterance meets the criteria for fasahah and baligh. Speakers must double-check and understand the relationship between one diction and another. 
Likewise, speakers must understand every grammatical form used to convey a particular communication function. Figure 3 is Jurjani's statement regarding this stage:

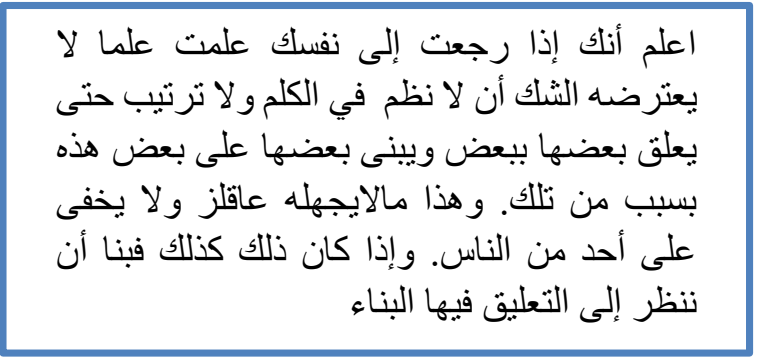

Figure 3 Al-Jurjani, Dalail al- I'jaz, 2016 • p.45

The process of producing discourse that meets the fashahah criteria of Jurjani's perspective is called the theory of al-Nudhm Jurjani. It has a similar thought expressed by one of the modern linguists of the generative transformative school, Noam Chomsky when explaining his theory of universal grammar. Chomsky explained that the meaning of a sentence is contained in its inner structure. This concept explains that grammar applies universally (applies to all languages on the planet). What is meant is that everyone expresses their thoughts starting from the semantic representation, semantic components, and deep structure. Semantic Representation is a concept or thought that the speaker/messenger wants to express (encoder). For example, before speaking, someone must have an idea first, which cannot be excluded. Semantic Components are units of thought to realize Semantic Representation. The Deep Structure means that Semantic Components can be seen through its internal structure. The inner structure can be realized in Phrase, Structure and Rules. In addition, the internal structure can also be realized in the lexicon.

The stages of al-Tandzim described by Jurjani are in line with the stages of semantic representation proposed by Chomsky. Similarly, the stages of albina' stages and explanations are the same as making a semantic representation into a semantic component. For example, when Jurjani told about the al-tartib, the term deep structure had the same explanation. Likewise, when Jurjani explained the stages of alTa'liq, the stages were in line with Chomsky's explanation of the surface structure.

If we understand it with the madhhab of intertextuality (al-tanash), one of the interesting conversations is who is influenced by whom. Is Jurjani influenced by Chomsky or Chomsky influenced by
Jurjani? A work born including thought born of course not just born, there are many things behind and affect the birth of that thought. Judging from when the theory was coined, we can logically say that Chomsky influenced al-Jurjani. Because the theory of al-Nadzm was born before universal grammar.

\subsection{The purpose of a Jurjani perspective Discourse}

Context is one of the most essential elements in the communication process, and is a direct determinant of the understanding of a discourse. It causes context to become an essential topic in pragmatic studies. One of the pragmatic studies examines the relationship between language symbols, indicators, and use [11]. Context has a vital role in revealing the meaning of the language symbols used to communicate.

To understand the context in al-Jurjani's perspective, of course, cannot be separated from the social, religious and cultural conditions that surround Jurjani. He lived in an era of debate between groups in the field of theology (asy'ariyah vs. mu'tazilah). The most considerable debate is the issue of i'jaz alQur'an. And the atmosphere of this debate greatly influenced the balaghah studies conducted by Jurjani with the characteristics of a sharp and argumentative dialogue. Knowing this aspect is very important to sharpen his thoughts about the context in his book dalail-al-i'jaz. This kind of opinion is also in line with modern linguists that we can't deny the role of social context in shaping the mission of discourse [12].

The discussion on the topic of context was initiated by Jurjani when he responded to what Qodli Abdul Jabbar said about "fashohah" and "al-lafadz". In refuting as shown in figure 4.

When Jurjani questioned his predecessors' opinion, he raised methodological questions related to the problem of "words, meanings and structures". Although the goal is debate on theological issues, he uses a language approach to achieve a more precise understanding, especially in addressing the issue of i'jaz al-Qur'an which was previously not widely used as a knife for analysis of studies by predecessor scholars. The linguistic approach used by Jurjani uses the principle of grammatical continuity and the truth of meaning revealed through the effectiveness of $n a h w u$ through text explanations and interprets it then explores it by interpreting semantic principles based on nahwu rules with al-tandziri al-taqbiqi method. It is what gave birth to his thoughts on context. 


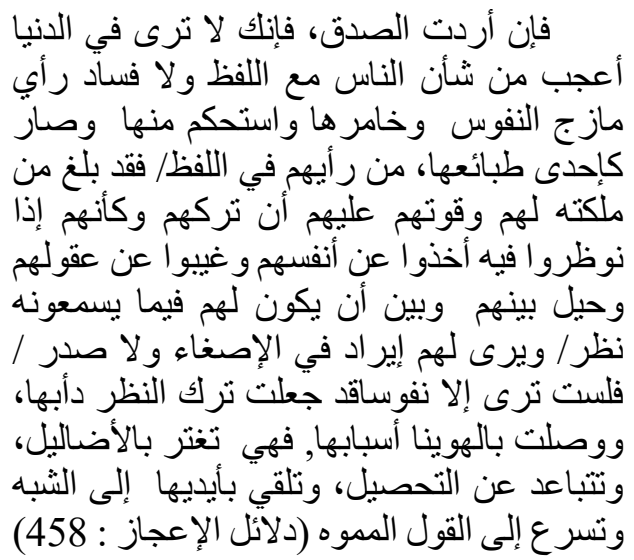

Figure 4 Al-Jurjani, Dalail al- I'jaz, 2016 .p. 458

This explanation of the al-tandziri al-tathbiqi method will be more understandable when he reveals about I'jazul Qur'an. Scholars agree that the miracle of the Qur'an lies in its fasohah. But Abdul Qahir alJurjani did not stop the discussion on that only, but he continued with the following question, namely why Balaghah and fashohah characterize the Qur'an. What aspect of the Qur'an is characterized by fashohah and balaghah. Responding to this question, Jurjani said that the strength of the Qur'an (balaghah and fashohah) lies in its meaning and pronunciation at the same time. It is not in line with his predecessor (Qodli Abdul Jabbar) who said that the fashohah and balaghah of the Qur'an lie in its word (lafadz). In interpreting fashohah, Jurjani combines internal and external validity at once. A lafadz cannot be said to be good if the word does not have a good meaning and the diction chosen to express the desired meaning, if these two conditions are met then the fashohah and balaghah criteria are met [13].

The term al-Nadzm was known by the Ash'ariyah madhhab (for example, the discussion conducted by Imam Baqilani) when they discussed the miracles of the Qur'an in terms of its "sentence". Then Abdul Qohir al-Jurjani made Nadzm a theory in the field of al-Ma'any Science which he described explicitly in his book entitled "Dalail al-I'jaz". Since the appearance of this book, al-Nadzm has become the center of his thoughts and theories, both in matters of $i^{\prime} j a z$ alQur'an, or literature in general. In Jurjani's view, the terms al-fashohah, al-balaghah, al-bayan, and albara'ah are synonyms he later called "al-nadzm" [13]. The value of the beauty and truth of a sentence cannot be judged separately by words or parts, but must be seen as a whole and as a whole. Therefore, Jurjani will not judge a word out of context.

In defining al-nadzm he said "a sentence is called al-nadzm when the sentence is grammatically correct, works according to grammatical rules and basics, is correct based on the method it has set and maintains the rules that have been set, all of those criteria must be met, fulfilled none can be lost" [13]. a critical point to consider by nadzm researchers is to understand the difference between "nahwu" which is better known as "i'rab" and the grammatical meanings known as "nadzm" understanding grammatical meanings and the synergy between grammatical meanings and psychological meanings [13].

His thinking about context is also seen in how he defines balaghah. According to him, balaghah is the suitability of a person's speech with the condition of the person being spoken to and the situation. It is also confirmed how he revealed the fashohah of a word depending on the synergy of word diction and the meaning of the word or sentence. Furthermore, in describing fasohah, Jurjani said that fashohah does not depend on the word diction already known or widely used. Still, its fashohah lies in how it is positioned in a sentence structure and how the meaning of the words in the sentence is matched [13]. If we look at Jurjani's expressions from a more global perspective, how he pays attention to the relationship between thinking and language.

If we examine the opinions of Abdul Qohir alJurjani carefully using modern linguistics, we will see several figures who agree with him. We note one phrase by Grace and Searle which says "we can't deny the role of social context in shaping the mission of a discourse" [12] Language cannot be understood only from its internal aspect but must be understood also from the psychological aspect of the speaker and the social environment that surrounds it [14]. Jurjani has discussed studies on socio-pragmatics since the 3rd century Hijriyah [13].

\subsection{Purpose in Discourse}

Learning from the background of Jurjani's thoughts from various references implies that the context that dominates him is the ideological context related to the madzhab he adheres to and the social context at that time. It gave birth to an argumentative style of language that dominated his works, especially dalail al-I. 'jaz. Arabic discourse is built on a varied cognitive field. Even though the discourse has one goal (for example, wanting to reveal the I'jaz alQur'an), it can generate various opinions and 
discourses. Therefore, determining the purpose of the discourse becomes essential. For example, when we say that the discourse of dalail al-i'jaz is a Jurjani productive process. We can question what the purpose of his discourse in his book is.

To answer the question about the purpose of discourse, many experts associate it with the language used, because the purpose is the core of communication between two parties. Therefore, the media used for communication, namely language, will be a central position to arrive at the goal of people to talk. Departing from this, understanding the purpose of Jurjani's discourse must relate to the language he uses. It means understanding the language from various aspects (grammatical, meaning and context of use. (Al-Shuhry, 2004). Let's look again at the definition of fashahah and Balaghah carried out by Jurjani. The intent or purpose of the discourse becomes an integral part of determining fashahah and balaghah. When Jurjani describes the process of language creativity, he divides the process of language creativity into two, linguistic and non-linguistic processes [13]. Non-linguistic processes are psychological and rational processes that attempt to dialogue between the intended meaning and select the proper diction to represent that meaning. This process is called by Jurjani the process of selection and choosing (amaliyat al-intiqa' wa al-ikhtiyar). The linguistic process begins with speech until it is produced the fruit of discourse as it has been designed in the mind.

The theme brought up by Jurjani aims to establish the idea that the balaghah of a utterance/discourse lies in the structure of the discourse and stylistics is different from previous theologians [15]. Therefore, he made nadzm the center of his discussion when trying to convey semantic theory. Interestingly, his delivery method prioritizes giving examples in explaining as a persuasive step so that others follow suit. Therefore, he often goes out of paradigmatic things towards pragmatic things. It is done by linking the existing lafadz in the structure according to the context data, and to strengthen that he presents the religious background. Therefore, the purpose he wants to convey is understood by the reader. Abid Al Jabiri praised the innovations made by Jurjani regarding his views on nadzm. According to him, the new thing that Jurjani did was analyzing the meaning of nadzm which was approached with argumentative characteristics in explaining uslub bayan in Arabic (such as majaz, isti'arah, kinayah and tamsil). Jabiri added that the argumentative characteristic can influence a person's thoughts with whom he communicates [16].
After understanding how to study the position goals in discourse, we can understand how Jurjani has preceded the pragmatic philosophers [17]. They gave birth to Speech Act Theory [18] conversational implicature (Grice) or implicit meaning in relevance theory [12].

\subsection{Jurjani's Perspective of Communication Mechanism}

Knowing about the context and purpose, this section concerns another aspect of pragmatics: the communication mechanism. When we talk about communication mechanisms, the critical point is how someone expresses the purpose of a discourse. The mechanism that then gives birth to communication strategies is an important thing to discuss in discussing how the intent or purpose is adequately conveyed.

If we pay attention to what Jurjani expressed in the book dalail al-i'jaz, he has chosen a very appropriate mechanism according to the context he is talking about to convey the desired goal when giving a discourse. Starting from diction choices to his logic in conveying the knowledge he wants to convey. He tries to realize the interactive principle in communication. The communication strategy can be seen from the following points: First, the gradation of the exposure in the sub-chapters contained in al-I'jaz's dalail starts from the opinions of the people who are the interlocutors, followed by how he thinks about things he disagrees with. With argumentative discourse techniques. Second, to strengthen his argument, he uses a persuasive strategy by bringing cognitive theoretical things to practical things both with words and actions. Third, persuasion that is carried out in discourse does not let go of other principles when discussing such as solidarity, giving directions, or associating. One example of a solidarity strategy is attribution in discourse, grammatical functional attributions can usually exceed pragmatic standards, which is usually an indication of the principle of solidarity. For example, the use of dhamir anta in communicating may not comply with grammatical rules, but this discrepancy is for pragmatic purposes of respecting the interlocutor. "اعلم أن ليس النظم إلا أن تضع : Example of his expression" كلامك الوضع الذي يقتضيه علم النحو...."

In addition to solidarity, there is another strategy that Jurjani uses in his discourse, namely the directing strategy (uslub al-taujih), which is a strategy that aims to direct the people who are invited to communicate to follow what Jurjani wants. What comes in is that uslub al-taujih is an order (uslub al-amr), asking (uslub al- 
thalab), forbidding (uslub al-nahy), warning (altahdzir) and also advising. And let's compare this with modern linguistic studies. The issues of this study are under the auspices of pragmatic anthropology, which among others discusses language politeness and sociopragmatics, which talks a lot about language functions.

\section{DISCUSSION}

What has been designed by Jurjani in al-nudhm theory is very important to pay attention to in providing pragmatic input in learning Arabic as a solution to the pragmatic failure experienced by Arabic language learners in Indonesia [1]. Maharah al-Qira'ah (reading skill) as one of the language receptive skills has a significant contribution in the formation of pragmatic competence of language learners. This text-based maharah qira'ah learning serves as the primary input in learning Arabic, especially in learning Arabic in Indonesia. And this theoretically also does not violate the concept of literacy-based language learning whose first cycle is modeling text. The primary key is how to choose the correct text that can lead language learners to have pragmatic competence. Another thing that is no less important is how the texts based on language were used to achieve the competency of maharah qiraah itself.

When used as the main ingredient in maharah alqiraah, language in use is returned to theoretical studies related to the types of texts that contain functional expressions, which are examples of texts that can lead language learners to have pragmatic competence. Based on these criteria, the selected texts contain functional expressions as follows: First, functional texts, which include descriptive text, recount text, procedural text, text, explanatory text, persuasive text, and argumentative text. Second, wellknown functional expressions have been officially agreed upon or well-known to be used by the community. Teachers use them as guidelines because both academics and practitioners often use them. This ta'bir includes: official administrative letters, personal letters, invitation announcements, reports, minutes of forms, speeches, remarks / opening or closing events, summarizing Third, unpopular functional expressions include debates, teaching materials, papers, documentation, lists references and footnotes, making lecture materials, buying and selling agreements.

Concerning how the texts have been determined as inputs, they are processed to achieve the competencies in maharah qiraah. Theoretically there are four gradations in classifying the competence of maharah al-qira'ah. Each gradation covers a variety of reading skills. Three essential gradations must be achieved in the competency of academic maharah qira'ah. First, the gradation of direct understanding includes reading skills, understanding the meaning of words according to the context, and parsing isytiqaq from new mufradat (vocabulary) in the text. In addition, it covers determining the general theme/topic of the text that becomes the teaching material, determining the main ideas in the paragraph, and determining the supporting thoughts in the paragraph. Also, it refers to the skill of determining the key sentences in the paragraph, understanding the time and place of the content in the text, understanding the logic of thinking knowledge contained in the text and the schedule and charts contained in the text.

Second, the gradation of productive interpretive understanding involves producing implied meanings in the text that the author does not clearly express, finding aspects of similarities and differences on matters related to the text's topics, and finding the connection information contained in the text. In addition, they can find the perspective and purpose of the author through the text presented, capture the mission and values raised by the author, find hidden information and deviations of ideas committed by the author.

Third, the gradation of critical understanding includes distinguishing main ideas and supporting ideas, sorting out which topics are related or not related to the theme, and distinguishing between theories and hypotheses. Besides, they can distinguish between essence and opinion or rational and irrational thoughts. They also can distinguish which arguments are weak or strong, justify the reference sources, novelty of information, the author's expertise, and validate the author's arguments. Further, they also can find which ideas come from primary and secondary sources, discover general ideas and innovative ideas

\section{CONCLUSION \& RECOMMENDATION}

There are four pragmatic aspects in Abdul Qahir al-Jurjani's thought. First, producing discourse with cycles as outlined in the theory of al-nadzm including al-tandzim, al-bina', al-tartib and al-ta'liq. When dialogued with modern linguistics, this stage aligns with Noam Chomsky's theory of universal grammar which includes; semantic representation, semantic component, deep structure and surface structure. Second, Context, in discussing the context of Abdul Qahir using the al-tandziri al-tathbiqi approach and more discussing the ideological context with a 
linguistic approach. Studying the context of Jurjani's perspective when dialogued with linguistics is closer to socio-pragmatic studies. Third, Positioning the Purpose in the discourse. In Jurjani's perspective, purpose is the most critical aspect of discourse. He builds the purpose of his discourse through varied cognitive fields even though the goal is one, namely $i^{\prime} j a z$ al-Qur'an. He argues that language creativity includes both linguistic and non-linguistic things. The non-linguistic domain is psychological and rational, which he calls amaliyat Intiqa' wal aliktiyar, while the linguistic domain includes producing the language. When dialogued with modern linguistics, studies like this are in line with studies on pragma-linguistics and socio-pragmatics. Fourth, the mechanism of discourse. His very prominent strategy in discourse is persuasive argumentation but is very thick with normative matters, especially related to language manners.

In solving pragmatic transfer problems, Jurjani's pragmatic thinking can be used in designing Arabic learning. First, Objective: in designing pragmaticbased teaching materials, the goal is to overcome pragmatic transfer. Second, the context of its preparation is a lack of pragmatic input causes that transfer. Therefore, the material is designed with various functional contexts needed daily. Third, the mechanism offered is to design teaching materials based on pragmatic input by having a dialogue between the pragmatic competencies of the Jurjani and Maharah Qira'ah perspectives.

Based on the findings of this study, the solution to the problem of learning Arabic can be done by conducting studies that raise the dialogue between turas Arabic and modern linguistics. The results of this dialogue are designed to be a language learning design implemented in learning classes and tested. In addition, action research is also carried out to solve various problems found in the classroom.

\section{REFERENCES}

[1] M. Hasanah, "Qadlaya al-Naqli al-Tadawuli fi muallafat Tammam Hassan wa ahammiyatuha fi Tashmim al-Manhaj al-Dirasi li al-Lughah alArabiyah li attalabah al-Indunisiyyin." Malang: Jamiah Maulana Malik Ibrahim al-Islamiyah alHukumiyah, 2014.

[2] M. Canale \& M. Swain. "Theoretical Bases of Communicative Approaches to Second Language Teaching and Testing". Applied Linguistics, vol. 1, no. 1, pp. 1-47, 1980
[3] G. Kasper, "Can pragmatic competence be taught?" NFLRC NetWork \#6, Honolulu: University of Hawai'i, Second Language Teaching \& Curriculum Center. 1997, http://www.11l.hawaii.edu/nflrc/NetWorks/NW6 I

[4] G. Kasper, \& K. R. Rose, "Pragmatic Development in a Second Language". Oxford: Blackwell. 2002

[5] J. Y. Jung "Issues in Acquisitional Pragmatic". 2004

[6] P. W. J. Nababan. "Ilmu Pragmatik: Teori dan Penerapannya' Jakarta: Depdikbud. 1987

[7] S. Behairy. "An Applied Linguistic Study: On the Relationship Between Structure and Semantics" Cairo: Zahrat al-Sharq. 1997.

[8] M. Rahardjo, "Metodologi Penelitian Kualitatif untuk ilmu-ilmu Sosial dan Humaniora dari Teori ke Praktik". Malang: Republik Media. 2020

[9] C. al-Wasilah. "Pokoknya Kualitatif". Jakarta: Pustaka Jaya. 2002

[10] al-Faqi, 'Isam al-Din 'Abd al-Ra'uf. Bilad alHind fi al-'Asr al-Islami Mundhu Fajr al-Islam wa Hatta al-Taqsim. Cairo: Dar al-Fikr al-'Arabi. 2002

[11] Van Dijk. “Al-Nash wa al-Siyaq: istiqsho' albahtsi fi al-khitab al-dilali wa al-Tadawuli." Translated Abdul Qadir Qonini. Afrika: Dal-alBaidla', 2000.

[12] J. R. Searle. "Expression and Meaning: Studies in the Theory of Speech Act". Cambridge University Press. 1979.

[13] Al Jurjani, Abu Bakr Abdul Qahir bin Abdur Rahman Dalailul i'jaz, Kairo: Maktabah al Khaniji, 2004

[14] M. Nasif. "Muhawarat mae alnashr alearabii". [Conversations with Arab]. Publishing. world of knowledge series. 1997.

[15] A. J. Al-Manqour. "ealm aldilalat 'usuluh wamabahithuh fi alturath alearabii." [Semantics: Its Origins and Investigations in the Arab Heritage], Damascus: Arab Writers Union Publications. 2001.

[16] M. A. Al-Jabri. "N aqd aleaql alearabii" [Criticism of the Arab mind], vol 1, no. 2, Beirut: Dar al-Tala'a, n.d. 
[17] A. Q. Al-Jurjani. "Dun alsanati 'asrar albalaghati" [Secrets of Rhetoric]. Read and commented by Mahmoud Mohamed Shaker. Jeddah: Dar Al-Madani, n.d.

[18] J. L. Austin. "How to do Thing with Words". Oxford: The Clarendon Press, 1962. 